\title{
Effectiveness of a sports-based HIV prevention intervention in the Dominican Republic: a quasi- experimental study
}

\author{
Z.A. Kaufman ${ }^{\mathrm{a}, \mathrm{b} *}$, R.L. Welsch ${ }^{\mathrm{a}, \mathrm{c}}$, J.D. Erickson ${ }^{\mathrm{d}}$, S. Craig ${ }^{\mathrm{a}}$, L.V. Adams ${ }^{\mathrm{e}}$ and D.A. Ross ${ }^{\mathrm{b}}$ \\ ${ }^{a}$ Department of Anthropology, Dartmouth College, Hanover, NH, USA; ${ }^{b}$ Department of Epidemiology and Population Health, \\ London School of Hygiene and Tropical Medicine, London, UK; ${ }^{c}$ Department of Anthropology, Franklin Pierce University, \\ Rindge, NH, USA; ${ }^{d}$ Rubenstein School of Environment and Natural Resources, University of Vermont, Burlington, VT, USA; \\ ${ }^{e}$ Department of Infectious Disease, Dartmouth Medical School, Hanover, NH, USA
}

(Received 14 December 2010; final version received 25 July 2011)

\begin{abstract}
Previous observational and quasi-experimental studies in sub-Saharan Africa have suggested the effectiveness of youth-targeted HIV prevention interventions using sport as an educational tool. No studies have yet assessed the effect of similar programs in the Caribbean. A quasi-experimental trial was conducted to assess the effectiveness of a sports-based intervention in six migrant settlements in the Puerto Plata Province of the Dominican Republic. A total of 397 structured interviews were conducted with 140 adolescents prior to, immediately following, and four months following 10-hour interventions using the Grassroot Soccer curriculum. Interview responses were coded, aggregated into composite scores, and analyzed using logistic regression, adjusting for baseline differences as well as age, sex, community, and descent. At post-intervention, significant differences were observed between groups in HIV-related knowledge $(\operatorname{adjOR}=13.02,95 \% \mathrm{CI}=8.26,20.52)$, reported attitudes $(\operatorname{adjOR}=12.01$, $95 \% \mathrm{CI}=7.61,18.94)$, and reported communication $(\operatorname{adjOR}=3.13,95 \% \mathrm{CI}=1.91,5.12)$. These differences remained significant at four-month follow-up, though declines in post-intervention knowledge were observed in the Intervention group while gains in knowledge and reported attitudes were observed in the Control group. Results suggest that this sports-based intervention could play a valuable role in HIV prevention efforts in the Caribbean, particularly those targeting early adolescents. Further evaluation of sports-based interventions should include indicators assessing behavioral and biological outcomes, longer-term follow-up, a larger sample, randomization of study participants, and strenuous efforts to minimize loss-to-follow-up.
\end{abstract}

Keywords: HIV; youth; sport; Dominican Republic; Caribbean

\section{Background}

Sport is becoming an increasingly popular tool in youth-targeted HIV prevention. Proponents, funders, and implementers argue that sport can play a valuable role in preventing HIV by engaging youth as community leaders, educating them about risk reduction, and building valuable communication and life skills to prevent risky sexual behavior (SDP IWG, 2008). The evidence supporting this approach, however, is limited. Two quasi-experimental studies on sports-based HIV prevention programs in Zimbabwe (Clark, Friedrich, Ndlovu, Neilands, \& McFarland, 2006) and Tanzania (Maro et al., 2009) found significant effects on HIV-related knowledge, reported attitudes, intentions, and perceived control in condom use. A recently published cross-sectional study found that participation in a sport-based HIV prevention program in Kenya was associated with greater self-reported condom use at first and last sex as well as higher reported frequency of condom use (Delva et al., 2010). No published evaluations have assessed sports-based HIV prevention interventions outside the African continent.

Outside of sub-Saharan Africa, the Caribbean has the highest regional HIV prevalence in the world, with $75 \%$ of its HIV-infected individuals living in Haiti and the Dominican Republic (DR) (PAHO, 2007; UNAIDS, 2008). In recent years, national prevalences in both the DR and Haiti have begun to decline, though immigrants, men having sex with men (Gaillard et al., 2006; Halperin, De Moya, PérezThen, Pappas, \& Garcia Calleja, 2009), and people who live in bateyes, impoverished settlements predominantly inhabited by Haitian immigrants and their children (CESDEM, 2007a), still remain vulnerable. Originally established as temporary work camps for sugarcane cutters, these geographically and socially isolated communities have become permanent settlements, where people endure substandard living conditions, suffer disproportionately from infectious diseases, and lack basic health services (Kreniske, 1997; Lopez Severino \& De Moya, 2007, Simmons, 2010). The 2007 Demographic and Health Survey in

*Corresponding author. Email: Zachary.Kaufman@1shtm.ac.uk 
DR found an adult HIV prevalence of $3.2 \%$ in bateyes, four times the national average of $0.8 \%$, and roughly 1.5 -times the Haitian national average of 2.2\% (CESDEM, 2007a; UNAIDS, 2008).

A growing proportion of Haitian immigrants live not in bateyes but in barrios predominantly inhabited by Haitian immigrants and their descendents (Ferguson, 2003). These communities, while more urban, reflect similar living conditions to bateyes, though little public health research has focused on these communities. Though predominantly Haitian, these barrios (as well as bateyes) are home to many Dominicans. Analysis of data from 2002 to 2006 at obstetrical sites in La Romana - a region with a substantial Haitian population, both in bateyes and barrios - revealed a significantly higher HIV prevalence among Haitian mothers than among Dominican mothers, with the difference being especially pronounced $(5.2 \%$ vs $2.3 \%)$ among mothers aged 21-25 years (Roman-Poueriet et al., 2009). Given this difference, it is important for HIV prevention studies within this population to consider participants' nationality (or descent, in the case of youth) as a potential risk factor.

The limited available data on HIV-related knowledge, attitudes, and beliefs among the Haitian migrant population in the DR suggests that prevention knowledge is low (Lopez Severino \& De Moya, 2007; Martinez, 2005). Stigma and belief in myths about HIV transmission are more common in bateyes than nationally, while the proportion of residents with comprehensive knowledge of HIV is nearly $30 \%$ lower (CESDEM, 2007b). Risky behavior is also of concern in bateyes, particularly multiple concurrent partnerships, dry sex practices, and early sexual debut (Halperin, 1999; Population Services International, 2006). Among young batey females, roughly a quarter report initiating sex before age 15 and about twothirds before age 18, compared to national averages of $15 \%$ and $51 \%$, respectively (CESDEM, 2007b). Nevertheless, more than $60 \%$ of 15 - to 19 -year-old batey youth perceive they have no risk of HIV infection and more than $85 \%$ perceive they have little or no risk (CESDEM, 2007b). While this underscores the need to reach batey adolescents with effective prevention programs, no published studies to date have assessed the outcomes of HIV prevention interventions serving this population.

The Fútbol Para la Vida (FPV) program, initiated at Batey Libertad, is a partnership between the University of Vermont, the Batey Libertad Coalition, the DREAM Project, and Grassroot Soccer. Drawing from lessons learned from a successful sports-based program in Zimbabwe (Clark et al., 2006), the partners trained local batey soccer players - role models in their communities - to deliver FPV interventions in community centers after school. The programs reached at-risk youth, including children not attending school, orphans, and other vulnerable children.

Using a Spanish version of the Grassroot Soccer curriculum (www.grassrootsoccer.org), FPV camps consist of 10 hours of instruction, typically administered over the course of five days. Each of the 13 activities has an interactive component and a discussion component. For example, in "Risk Field," participants dribble a soccer ball through cones representing HIV-related risks - unprotected sex, multiple partners, drugs and alcohol, older sexual partners, etc. If one player hits a cone, the participant and his or her teammates must complete three pushups, showing how the consequences of one person's risk can not only affect him or her, but also friends, family, and the community. Other activities follow this same pattern of soccer-themed, interactive, discovery-based learning. The program aims to improve youths' knowledge about HIV and AIDS, to engender a feeling that they can protect themselves from contracting the virus, and to foster an open environment in which they feel comfortable discussing sexual and reproductive health issues amongst peers and with community role models. With these objectives in mind, this study assessed the short-term outcomes of FPV interventions to determine whether they significantly influenced what young people knew, thought, and communicated about HIV and whether any observed effects were sustained over several months.

\section{Methods}

Structured face-to-face interviews were conducted at baseline with 164 adolescents aged 10-20 years in four bateyes and two Haitian barrios in the north coast province of Puerto Plata. ${ }^{1}$ All participants were invited to participate in a five-day FPV camp. Ninetynine chose to participate (the Intervention group), 41 chose not to participate (the Control group), and 24 were lost-to-follow-up. Baseline characteristics of the two groups are presented in Table 1. The median age of study participants was 13 years, with the Control group (median $=14$ years) being slightly older than the Intervention group (median $=13$ years, $t=1.94$, $p=0.056$ ). Forty-seven per cent of the study participants were female and $79 \%$ identified as being of Haitian descent, with no significant differences in sex or descent across groups. Interviews were conducted prior to, immediately following, and four months after the program. At follow-up, 24 Intervention 
Table 1. Group characteristics and knowledge, reported attitudes, and reported communication at baseline.

\begin{tabular}{|c|c|c|c|c|}
\hline & $\begin{array}{l}\text { Intervention } \\
\quad(n=99)\end{array}$ & $\begin{array}{l}\text { Control } \\
(n=41)\end{array}$ & $\begin{array}{l}\text { Unadjusted } t \text { - or } \\
z \text {-test }\end{array}$ & \\
\hline \multicolumn{5}{|l|}{ Demographics } \\
\hline Mean age (standard deviation) & 13.5 years $(2.3)$ & $\begin{array}{l}14.4 \text { years } \\
(2.2)\end{array}$ & $t=1.93, p=0.06$ & \\
\hline Female & $47.5 \%(47 / 99)$ & $\begin{array}{l}46.3 \%(19 / \\
41)\end{array}$ & $z=0.12, p=0.90$ & \\
\hline \multirow[t]{2}{*}{ Haitian descent } & $77.8 \%(77 / 99)$ & $\begin{array}{l}80.5 \%(33 / \\
41)\end{array}$ & $z=0.77, p=0.44$ & \\
\hline & \multicolumn{2}{|c|}{$\%$ 'Correct' responses $(n / N)$} & $\begin{array}{l}\text { Unadjusted OR } \\
(95 \% \mathrm{CI})\end{array}$ & $\begin{array}{l}\text { Adjusted OR } \\
(95 \% \mathrm{CI})^{\mathbf{a}}\end{array}$ \\
\hline \multicolumn{5}{|l|}{ Knowledge (correct response) } \\
\hline How is sida transmitted? (sex) & $59 \%(58 / 99)$ & $68 \%(28 / 41)$ & $0.66(0.30-1.42)$ & $0.90(0.38-2.12)$ \\
\hline $\begin{array}{l}\text { Is sida transmitted by sharing a drinking glass? } \\
\text { (No) }\end{array}$ & $56 \%(51 / 91)$ & $63 \%(26 / 41)$ & $0.74(0.34-1.57)$ & $0.97(0.42-2.28)$ \\
\hline $\begin{array}{l}\text { How can a person protect themselves from sida? } \\
\text { (Faithfulness/partner reduction) }\end{array}$ & $1 \%(1 / 99)$ & $2 \%(1 / 41)$ & $0.41(0.02-6.69)$ & $0.68(0.24-18.84)$ \\
\hline $\begin{array}{l}\text { How can a person protect themselves from sida? } \\
\text { (using condoms) }\end{array}$ & $52 \%(51 / 99)$ & $61 \%(25 / 41)$ & $0.68(0.32-1.43)$ & $0.92(0.37-2.28)$ \\
\hline Are HIV and AIDS the same thing? (No) & $28 \%(28 / 99)$ & $32 \%(13 / 41)$ & $0.85(0.39-1.87)$ & $0.90(0.39-2.07)$ \\
\hline Can sida be cured? (No) & $64 \%(63 / 99)$ & $73 \%(30 / 41)$ & $0.64(0.29-1.43)$ & $0.64(0.28-1.48)$ \\
\hline Overall knowledge & $44 \%(257 / 586)$ & $\begin{array}{l}50 \%(123 / \\
246)\end{array}$ & $0.75(0.56-1.02)$ & $0.89(0.65-1.22)$ \\
\hline \multicolumn{5}{|l|}{ Reported attitudes ('correct' response) } \\
\hline Can you protect yourself from sida? (Yes) & $56 \%(55 / 99)$ & $76 \%(31 / 41)$ & $0.40(0.18-0.91)^{*}$ & $0.46(0.20-1.09)$ \\
\hline Is contracting sida a question of bad luck? (No) & $21 \%(21 / 98)$ & $24 \%(10 / 41)$ & $0.85(0.36-2.00)$ & $0.97(0.39-2.40)$ \\
\hline $\begin{array}{l}\text { Can someone control whether or not they get sida? } \\
\text { (Yes) }\end{array}$ & $41 \%(41 / 99)$ & $49 \%(20 / 41)$ & $0.74(0.36-1.54)$ & $0.89(0.41-1.92)$ \\
\hline Can a person with sida live a normal life? (Yes) & $35 \%(34 / 98)$ & $37 \%(15 / 41)$ & $0.97(0.45-2.07)$ & $1.02(0.47-2.24)$ \\
\hline $\begin{array}{l}\text { What would you do if you found out your friend } \\
\text { had sida? (support/help them) }\end{array}$ & $41 \%(28 / 68)$ & $23 \%(6 / 26)$ & $2.28(0.81-6.38)$ & $\begin{array}{l}3.72(1.13- \\
12.16)^{*}\end{array}$ \\
\hline Overall attitudes & $39 \%(179 / 462)$ & $\begin{array}{l}43 \%(82 / \\
190)\end{array}$ & $0.84(0.60-1.18)$ & $0.97(0.68-1.39)$ \\
\hline \multicolumn{5}{|l|}{ Reported communication ('correct' response) } \\
\hline Are you comfortable talking about sida? (Yes) & $55 \%(54 / 99)$ & $63 \%(26 / 41)$ & $0.72(0.34-1.53)$ & $0.80(0.37-1.73)$ \\
\hline $\begin{array}{l}\text { With whom have you talked about sida? } \\
\text { (mentioned at least one family member) }\end{array}$ & $24 \%(20 / 84)$ & $22 \%(8 / 37)$ & $1.13(0.45-2.87)$ & $1.05(0.40-2.74)$ \\
\hline $\begin{array}{l}\text { With whom have you talked about sida? } \\
\text { (mentioned at least one friend) }\end{array}$ & $34 \%(34 / 99)$ & $41 \%(17 / 41)$ & $0.74(0.35-1.56)$ & $0.88(0.40-1.94)$ \\
\hline $\begin{array}{l}\text { Can you name } 3 \text { people with whom you can speak } \\
\text { about sida? (Yes) }\end{array}$ & $59 \%(58 / 99)$ & $66 \%(27 / 41)$ & $0.73(0.34-1.57)$ & $0.77(0.35-1.68)$ \\
\hline Overall communication & $44 \%(166 / 381)$ & $\begin{array}{l}49 \%(78 / \\
160)\end{array}$ & $0.82(0.56-1.18)$ & $0.88(0.60-1.29)$ \\
\hline
\end{tabular}

${ }^{\mathrm{a}}$ Adjusted for age, sex, community, and descent.

${ }^{*} p<0.05$, not below Bonferroni-adjusted critical value.

participants and 22 Control participants had been lost-to-follow-up (see Figure 1).

The interview schedule included 15 indicators assessing HIV-related knowledge, attitudes and communication (KAC). Through pilot testing with 45 youth (non-study participants) in two of the communities, the instrument was calibrated to ensure that questions were understood and translated appropriately. Notably, during pilot testing, the use of the term VIH (HIV) confused the majority of youth, who had only heard the virus referred to as Sida (AIDS). Thus, the term SIDA was used in the study's interviews, with the exception of two questions: whether HIV and AIDS were the same thing and whether a person with HIV could live a normal life. The schedule utilized both agree/disagree questions and open-ended questions regarding HIV transmission and prevention. For open-ended questions, answers 


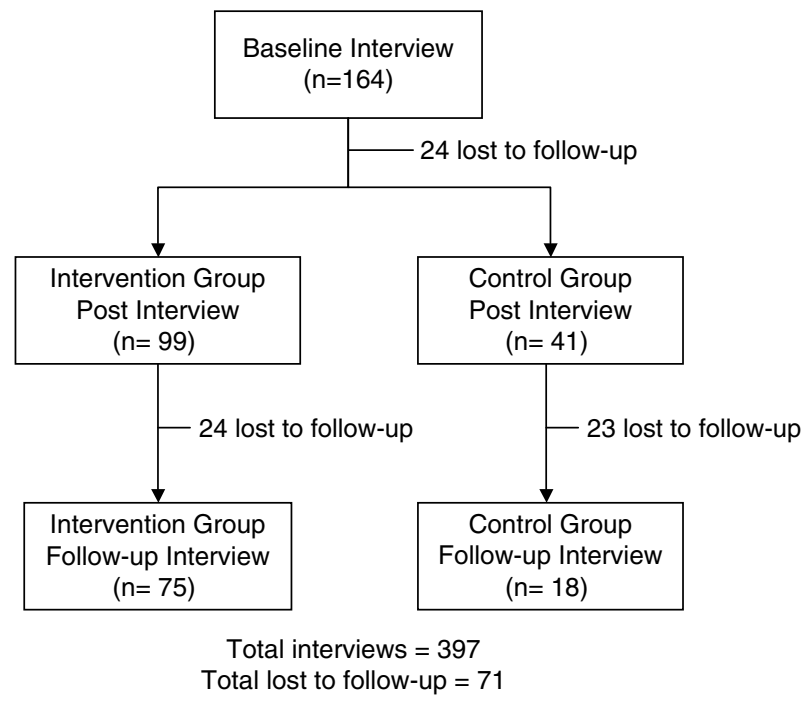

Figure 1. Flow chart of study participants and data collection points.

were post-coded, with spontaneous mention of the desired answer being coded as a "correct" response. When participants provided any response to "How can a person avoid getting sida?" they were asked to name additional methods of prevention until they could not think of any more. Mention of "condoms" and mention of "faithfulness" were coded separately and answers that implied condoms (e.g., "using protection") or faithfulness (e.g., "not sleeping around" or "having just one partner") were coded as correct.

Overall composite indicators for knowledge, reported attitudes, and reported communication were created as the overall proportion of "correct" responses in each of the three categories. The proportions of "correct" responses for individual and composite indicators were analyzed comparing the two groups at pre, post and follow-up using logistic regression in Stata. All analyses were adjusted for age, sex, community, and descent (i.e., whether participants self-identified primarily as Dominican or Haitian). Post and follow-up analyses were adjusted for baseline differences. For all tests, interpretation of $p$ values was adjusted using the Bonferroni Correction to allow for multiple comparisons.

\section{Results}

After adjusting for age, sex, community and descent, no significant differences were observed at baseline between the Intervention and Control groups in overall knowledge $($ adjOR $=0.89,95 \% \mathrm{CI}=0.65$, 1.22), overall reported attitudes (adjOR $=0.97,95 \%$ $\mathrm{CI}=0.68,1.39)$, or overall reported communication
(adjOR $=0.88,95 \% \mathrm{CI}=0.60,1.29)$. While the older Control group scored slightly higher on 13 out of the 15 indicators, both groups demonstrated low proportions of "correct" responses. A strikingly high proportion of adolescents (42\%) reported believing that sida can be transmitted by sharing a drinking glass with an infected person. Numerous other myths about transmission surfaced, for example, that sida can be spread by touching, kissing, hugging, eating off the same plate, sharing eating utensils, using the same bathroom, wearing the same clothing, sleeping in the same bed, or living with an infected person. When asked how sexually active people can protect themselves from sida, only two adolescents mentioned faithfulness or partner reduction, whereas roughly $50 \%$ mentioned condoms. Fewer than one in four youth reported having spoken with a family member about Sida and only 36\% reported having spoken about it with a friend.

After adjusting for baseline responses as well as age, sex, community and descent, significant differences were observed between groups at post (immediately following intervention) in overall knowledge (adjOR $=8.40,95 \% \quad \mathrm{CI}=6.45,10.94)$, reported attitudes $(\operatorname{adjOR}=9.58,95 \% \mathrm{CI}=6.92,13.27)$ and communication $($ adjOR $=3.31,95 \% \mathrm{CI}=2.44,4.50$ ) (Table 2 and Figure 2). The strongest specific effects were observed on knowledge of the sexual transmission of Sida $(\operatorname{adjOR}=116.4,95 \% \mathrm{CI}=15.3,886.2$ ), knowledge of condoms as a prevention method $($ adjOR $=59.4,95 \% \mathrm{CI}=13.0,270.8)$ and self-efficacy to avoid Sida (adjOR $=54.0,95 \%$ CI $=9.73$, 299.4). The Intervention group scored higher than the Control group on all 15 indicators, with significant differences being observed for 12 of the indicators, even after the Bonferroni adjustment $(p<0.003)$. One attitudinal indicator showed a borderline effect $(p=0.004)$ that did not fall below the Bonferroniadjusted critical $p$-value. The least difference was observed in reported communication with a friend about Sida (adjOR $=1.96,95 \% \mathrm{CI}=0.81-4.76$ ) and reported comfort in talking about Sida (adjOR = $2.28,95 \% \mathrm{CI}=0.73,7.13$ ) (Table 2).

Adjusting for age, sex, community, descent and baseline responses had a large effect on the magnitude of effect for some specific indicators. Most notably, for knowledge of the sexual transmission of HIV, adjustment increased the odds ratio from 20.48 to 116.43. Adjustment effected significance for two indicators - reported communication with a family member and being able to name three people with whom the participant could speak about sida - which had unadjusted $p$ values of 0.017 and 0.027 , respectively. Whereas the adjusted effect for these indicators met the Bonferroni significance criteria $(p<0.003)$, 
Table 2. Differences in knowledge, reported attitudes, and reported communication immediately post-intervention.

\begin{tabular}{|c|c|c|c|c|}
\hline & \multicolumn{2}{|c|}{$\%$ 'Correct' responses $(\boldsymbol{n} / \boldsymbol{N})$} & \multirow[b]{2}{*}{$\begin{array}{l}\text { Unadjusted OR } \\
\qquad(95 \% \mathrm{CI})\end{array}$} & \multirow[b]{2}{*}{$\begin{array}{l}\text { Adjusted OR } \\
\qquad(95 \% \mathrm{CI})^{\mathrm{a}}\end{array}$} \\
\hline & $\begin{array}{l}\text { Intervention } \\
\qquad(n=99)\end{array}$ & $\begin{array}{l}\text { Control } \\
(n=41)\end{array}$ & & \\
\hline \multicolumn{5}{|l|}{ Knowledge (correct response) } \\
\hline How is sida transmitted? (sex) & $97 \%(96 / 99)$ & $61 \%(25 / 41)$ & $20.5(5.53-75.8)^{* *}$ & $116.4(15.3-886.2)^{* *}$ \\
\hline $\begin{array}{l}\text { Is sida transmitted by sharing a drinking } \\
\text { glass? (No) }\end{array}$ & $97 \%(89 / 92)$ & $61 \%(25 / 41)$ & $19.0(5.12-70.4)^{* *}$ & $51.6(10.3-258.5)^{* *}$ \\
\hline $\begin{array}{l}\text { How can a person protect themselves } \\
\text { from sida? (faithfulness/partner } \\
\text { reduction) }\end{array}$ & $34 \%(34 / 99)$ & $5 \%(2 / 41)$ & $10.2(2.32-44.8)^{* *}$ & $24.6(3.13-194.0)^{* *}$ \\
\hline $\begin{array}{l}\text { How can a person protect themselves } \\
\text { from sida? (using condoms) }\end{array}$ & $96 \%(95 / 99)$ & $54 \%(22 / 41)$ & $20.5(6.34-66.3)^{* *}$ & $59.4(13.0-270.8)^{* *}$ \\
\hline Are HIV and AIDS the same thing? (No) & $89 \%(88 / 99)$ & $46 \%(19 / 41)$ & $9.26(3.86-22.3)^{* *}$ & $12.2(4.67-32.0)^{* *}$ \\
\hline Can sida be cured? (No) & $92 \%(91 / 99)$ & $61 \%(25 / 41)$ & $7.28(2.80-19.0)^{* *}$ & $13.7(4.34-43.4)^{* *}$ \\
\hline Overall knowledge & $83 \%(486 / 587)$ & $48 \%(118 / 246)$ & $5.69(4.08-7.94)^{* *}$ & $13.02(8.26-20.52)^{* *}$ \\
\hline \multicolumn{5}{|l|}{ Reported attitudes ('correct' response) } \\
\hline Can you protect yourself from sida? (Yes) & $97 \%(96 / 99)$ & $61 \%(25 / 41)$ & $20.5(5.53-75.8)^{* *}$ & $54.0(9.73-299.4)^{* *}$ \\
\hline $\begin{array}{l}\text { Is contracting sida a question of bad luck? } \\
\text { (No) }\end{array}$ & $76 \%(75 / 99)$ & $29 \%(12 / 41)$ & $7.55(3.34-17.1)^{* *}$ & $26.9(7.39-98.1)^{* *}$ \\
\hline $\begin{array}{l}\text { Can someone control whether or not they } \\
\text { get sida? (Yes) }\end{array}$ & $78 \%(77 / 99)$ & $56 \%(23 / 41)$ & $2.74(1.26-5.96)^{*}$ & $3.65(1.51-8.80)^{*}$ \\
\hline $\begin{array}{l}\text { Can a person with sida live a normal life? } \\
\text { (Yes) }\end{array}$ & $81 \%(80 / 99)$ & $46 \%(19 / 41)$ & $4.88(2.21-10.76)^{* *}$ & $7.80(3.03-20.1)^{* *}$ \\
\hline $\begin{array}{l}\text { What would you do if you found out your } \\
\text { friend had sida? (support/help them) }\end{array}$ & $91 \%(75 / 82)$ & $22 \%(9 / 40)$ & $36.9(12.6-107.9)^{* *}$ & $51.7(13.8-193.7)^{* *}$ \\
\hline Overall attitudes & $84 \%(403 / 478)$ & $43 \%(88 / 204)$ & $7.08(4.89-10.3)^{* *}$ & $12.01(7.61-18.94)^{* *}$ \\
\hline \multicolumn{5}{|c|}{ Reported communication ('correct' response) } \\
\hline $\begin{array}{l}\text { Are you comfortable talking about sida? } \\
\text { (Yes) }\end{array}$ & $86 \%(85 / 99)$ & $78 \%(32 / 41)$ & $1.71(0.67-4.33)$ & $2.28(0.73-7.13)$ \\
\hline $\begin{array}{l}\text { With whom have you talked about sida? } \\
\text { (mentioned at least one family member) }\end{array}$ & $54 \%(45 / 84)$ & $30 \%(11 / 37)$ & $2.73(1.20-6.22)^{*}$ & $5.70(1.69-19.2)^{* *}$ \\
\hline $\begin{array}{l}\text { With whom have you talked about sida? } \\
\text { (mentioned at least one friend) }\end{array}$ & $56 \%(56 / 99)$ & $51 \%(21 / 41)$ & $1.24(0.60-2.57)$ & $1.96(0.81-4.76)$ \\
\hline $\begin{array}{l}\text { Can you name } 3 \text { people with whom you } \\
\text { can speak about sida? (Yes) }\end{array}$ & $87 \%(86 / 99)$ & $71 \%(29 / 41)$ & $2.74(1.12-6.66)^{*}$ & $6.21(1.96-19.6)^{* *}$ \\
\hline Overall communication & $71 \%(272 / 381)$ & $58 \%(93 / 160)$ & $1.80(1.22-2.64)^{* *}$ & $3.13(1.91-5.12)^{* *}$ \\
\hline
\end{tabular}

${ }^{\mathrm{a}}$ Adjusted for age, sex, community, descent, and baseline responses. ${ }^{*} p<0.03$, not below Bonferroni-adjusted critical value.

$* * p<0.003$, below Bonferonni-adjusted critical value.

the unadjusted effect did not. Adjustment had no effect on significance for composite indicators or for other specific indicators.

At follow-up (four months), significant differences between groups were again observed in overall knowledge $($ adjOR $=3.81,95 \% \mathrm{CI}=2.26,6.42)$, reported attitudes $(\operatorname{adjOR}=6.31,95 \% \mathrm{CI}=3.51$, 11.3 ), and reported communication (adjOR $=2.67$, $95 \% \mathrm{CI}=1.37,5.10) \quad($ Table 2). Adjustment again affected the estimated magnitude of effect, though it only influenced significance in overall reported communication (unadj $\mathrm{OR}=2.11,95 \% \mathrm{CI}=1.23$, $3.62, p=0.006)$. Overall knowledge declined for the Intervention group (from $83 \%$ immediately post- intervention to $78 \%$ four months after) but increased for the Control group (from $48 \%$ to $56 \%$ ), resulting in a diminished effect, as compared with the post analysis. Declines in effect on attitudes and communication were less notable (see Figure 2). In terms of individual indicators, the Intervention group again scored higher than the Control group on all 15 indicators. After the Bonferroni adjustment, significant differences between groups on specific indicators were only observed on one knowledge indicator and two attitude indicators. Loss-to-follow-up had resulted in wider confidence intervals. Two knowledge indicators and one attitude indicator had results of 


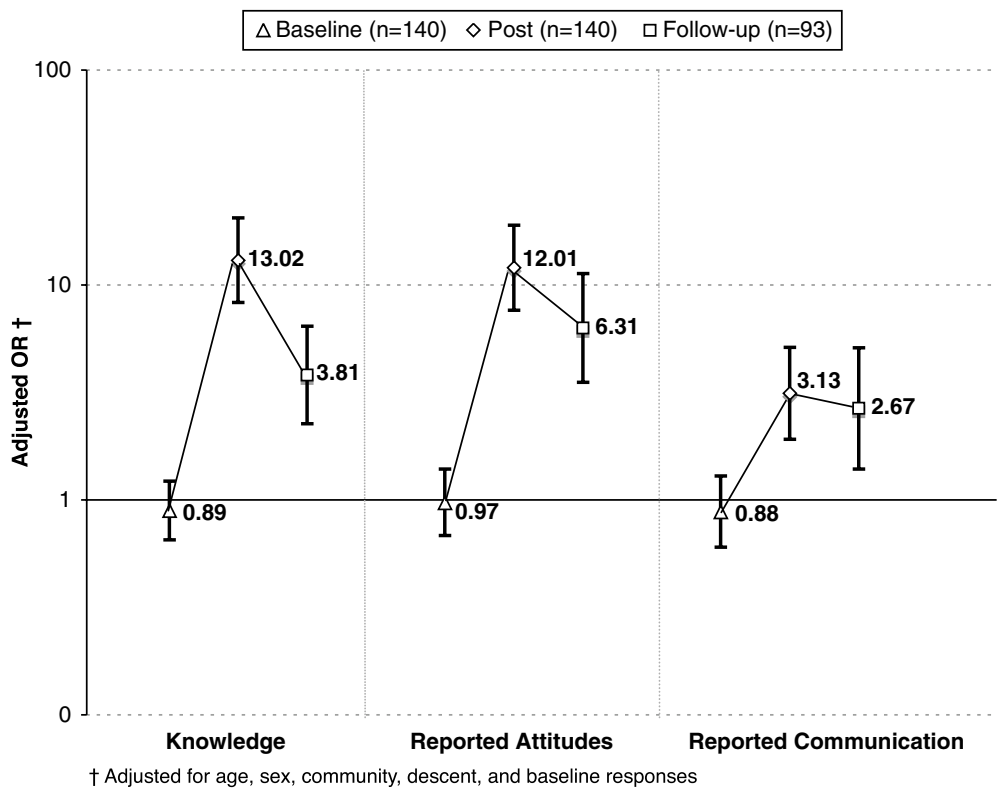

Figure 2. Differences in knowledge, reported attitudes, and reported communication between groups at post and follow-up.

borderline significance $(0.01<p<0.05)$ that did not pass the Bonferroni-adjusted critical $p$-value (see Table 3).

\section{Discussion}

These study results provide strong evidence of the FPV program's effect on HIV-related knowledge, reported attitudes, and reported communication (KAC). Though the Control group had slight advantages in $\mathrm{KAC}$ at baseline, the Intervention Group had surpassed them on every indicator by postintervention and retained these advantages at fourmonth follow-up. Similar to other studies on HIV prevention interventions, the findings point to a diminishing effect on knowledge over time.

From post-intervention to follow-up, the Intervention group notably declined in knowledge of partner reduction/mutual faithfulness as a prevention method (from $34 \%$ to $17 \%$ ), knowledge of condoms as a prevention method (from $96 \%$ to $89 \%$ ), and in knowledge of Sida being incurable (from $92 \%$ to $84 \%$ ). The effect on attitudes diminished as well, though not as markedly.

That knowledge of condoms as a prevention method greatly exceeded that of partner reduction/ faithfulness is important for tailoring prevention efforts in bateyes. The discrepancy likely results because past HIV prevention efforts have largely revolved around social marketing and condom promotion, including free condom distribution, posters, and a television drama. The use of an open-ended question to measure knowledge of prevention methods likely resulted in lower levels of knowledge (particularly around partner reduction) than would be found in a prompted health survey. However, since all participants had the opportunity to provide multiple answers, the unprompted question allowed investigation of adolescents' prioritization of HIV prevention strategies. In this case, both before and after the intervention, participants overwhelmingly emphasized condom use. That participants did not retain knowledge of partner reduction/faithfulness as a prevention method as well over the follow-up period as knowledge of condoms or HIV transmission highlights a key area for improvement in FPV. Indeed, this is an area in which many HIV prevention interventions have fallen short (Shelton et al., 2004). Activities in the FPV curriculum should be modified or supplemented to increase emphasis on partner reduction/faithfulness as a prevention method without detracting from education about abstinence and condoms.

This study had important limitations. Self-selection into groups might have introduced selection bias. For example, those choosing to participate in FPV might, by their nature, have been more likely to improve in knowledge, attitudes and communication. The lack of differences between groups at baseline suggests that the groups did not differ with respect to previous exposure to HIV-related information or interventions. Furthermore, since differences in age, sex, community, and ethnicity were adjusted for in the analysis, it is improbable that the major differences after exposure to the interventions resulted from differences in the make-up of the two groups. Nevertheless, in future evaluations of these interventions, 
Table 3. Differences in knowledge, reported attitudes, and reported communication at four-month follow-up.

\begin{tabular}{|c|c|c|c|c|}
\hline & \multicolumn{2}{|c|}{$\%$ 'Correct' responses $(n / N)$} & \multirow[b]{2}{*}{$\begin{array}{l}\text { Unadjusted OR } \\
\qquad(95 \% \mathrm{CI})\end{array}$} & \multirow[b]{2}{*}{$\begin{array}{l}\text { Adjusted OR } \\
(95 \% \mathrm{CI})^{\mathbf{a}}\end{array}$} \\
\hline & $\begin{array}{l}\text { Intervention } \\
\quad(n=75)\end{array}$ & $\begin{array}{l}\text { Control } \\
(n=18)\end{array}$ & & \\
\hline \multicolumn{5}{|l|}{ Knowledge (correct response) } \\
\hline How is sida transmitted? (sex) & $95 \%(71 / 75)$ & $78 \%(14 / 18)$ & $5.07(1.13-22.7)^{*}$ & $7.19(1.28-40.4)^{*}$ \\
\hline $\begin{array}{l}\text { Is sida transmitted by sharing a drinking glass? } \\
(\mathrm{No})\end{array}$ & $96 \%(72 / 75)$ & $78 \%(14 / 18)$ & $6.86(1.38-34.0)^{*}$ & $12.3(1.65-92.2)^{*}$ \\
\hline $\begin{array}{l}\text { How can a person protect themselves from } \\
\text { sida? (faithfulness/partner reduction) }\end{array}$ & $17 \%(13 / 75)$ & $6 \%(1 / 18)$ & $3.56(0.43-29.2)$ & $4.23(0.47-37.8)$ \\
\hline $\begin{array}{l}\text { How can a person protect themselves from } \\
\text { sida? (using condoms) }\end{array}$ & $89 \%(67 / 75)$ & $72 \%(13 / 18)$ & $3.22(0.91-11.4)$ & $3.46(0.94-12.7)$ \\
\hline Are HIV and AIDS the same thing? (No) & $85 \%(64 / 75)$ & $28 \%(5 / 18)$ & $15.1(4.49-50.9)^{* *}$ & $18.8(4.99-70.8)^{* *}$ \\
\hline Can sida be cured? (No) & $84 \%(63 / 75)$ & $78 \%(14 / 18)$ & $1.50(0.42-5.35)$ & $2.10(0.52-8.37)$ \\
\hline Overall knowledge & $78 \%(350 / 450)$ & $56 \%(61 / 108)$ & $2.70(1.74-4.19)^{* *}$ & $3.81(2.26-6.42)^{* *}$ \\
\hline \multicolumn{5}{|l|}{ Attitudes ('correct' response) } \\
\hline Can you protect yourself from sida? (Yes) & $96 \%(72 / 75)$ & $83 \%(15 / 18)$ & $4.80(0.88-26.1)$ & $5.69(0.91-35.5)$ \\
\hline Is contracting sida a question of bad luck? (No) & $76 \%(57 / 75)$ & $33 \%(6 / 18)$ & $6.33(2.08-19.3)^{* *}$ & $18.0(3.59-90.1)^{* *}$ \\
\hline $\begin{array}{l}\text { Can someone control whether or not they get } \\
\text { sida? (Yes) }\end{array}$ & $79 \%(59 / 75)$ & $61 \%(11 / 18)$ & $2.35(0.78-7.03)$ & $2.18(0.70-6.79)$ \\
\hline Can a person with sida live a normal life? (Yes) & $81 \%(61 / 75)$ & $56 \%(10 / 18)$ & $3.49(1.16-10.43)^{*}$ & $4.30(1.29-14.3)^{*}$ \\
\hline $\begin{array}{l}\text { What would you do if you found out your } \\
\text { friend had sida? (support/help them) }\end{array}$ & $87 \%(58 / 67)$ & $28 \%(5 / 18)$ & $16.8(4.81-58.4)^{* *}$ & $21.6(5.42-86.3)^{* *}$ \\
\hline Overall attitudes & $84 \%(307 / 367)$ & $52 \%(47 / 90)$ & $4.68(2.85-7.70)^{* *}$ & $6.31(3.51-11.3)^{* *}$ \\
\hline \multicolumn{5}{|l|}{ Communication ('correct' response) } \\
\hline Are you comfortable talking about sida? (Yes) & $91 \%(68 / 75)$ & $78 \%(14 / 18)$ & $2.78(0.71-10.8)$ & $4.85(0.77-30.4)$ \\
\hline $\begin{array}{l}\text { With whom have you talked about sida? } \\
\text { (mentioned at least one family member) }\end{array}$ & $58 \%(37 / 64)$ & $33 \%(6 / 18)$ & $2.74(0.91-8.22)$ & $3.04(0.94-9.86)$ \\
\hline $\begin{array}{l}\text { With whom have you talked about sida? } \\
\text { (mentioned at least one friend) }\end{array}$ & $61 \%(46 / 75)$ & $44 \%(8 / 18)$ & $1.98(0.70-5.61)$ & $1.92(0.62-5.98)$ \\
\hline $\begin{array}{l}\text { Can you name } 3 \text { people with whom you can } \\
\text { speak about sida? (Yes) }\end{array}$ & $87 \%(65 / 75)$ & $78 \%(14 / 18)$ & $1.86(0.51-6.78)^{\wedge}$ & $1.99(0.51-7.70)$ \\
\hline Overall communication & $75 \%(216 / 289)$ & $58 \%(42 / 72)$ & $2.11(1.23-3.62)^{*}$ & $2.67(1.39-5.10)^{* *}$ \\
\hline
\end{tabular}

${ }^{\mathrm{a} A d j u s t e d ~ f o r ~ a g e, ~ s e x, ~ c o m m u n i t y, ~ d e s c e n t, ~ a n d ~ b a s e l i n e ~ r e s p o n s e s . ~}$

${ }^{*} p<0.05$, not below Bonferroni-adjusted critical value.

${ }_{* *} p<0.003$, below Bonferonni-adjusted critical value.

participants or (clusters of participants) should be randomly allocated to Intervention and Control groups.

The study's small sample size limited our ability to analyze effects across sub-groups. Furthermore, lossto-follow-up rates in these transitory migrant communities were higher than anticipated. Among the Intervention group, this may have biased follow-up data. It is possible that those participants lost to follow-up would have scored lower than those interviewed at follow-up, resulting in larger overall declines in KAC between post-intervention and follow-up. Likewise, high loss-to-follow-up rates among the Control group limited the statistical power in followup analyses and made it difficult to determine to what extent information may have diffused from FPV participants to non-participants in the same community. Previous evaluation of the Grassroot Soccer model has suggested that diffusion may take place when interventions are delivered in a school setting (Clark et al., 2006). The extent and characteristics of this diffusion should be investigated in future studies.

Notably, the study did not include measures of reported sexual risk behavior or biological endpoints. This limits what can be inferred about the intervention's effect in preventing HIV transmission. The intervention's and study's short-term nature may have led to substantial desirability bias if we had assessed self-reported behavioral outcomes, particularly those related to sexual behavior. Numerous studies have confirmed that such measurements while important in measuring effectiveness - are subject to desirability bias, even within long-term follow-up periods (Plummer et al., 2004). Our study's small size, limited funding, and short-term scope did not allow for an assessment of biological outcomes. 
Indeed, youth-targeted HIV prevention interventions that have found short- and long-term effects on knowledge and attitudes have so far failed to demonstrate long-term impacts on HIV incidence (Cowan et al., 2010; Jewkes et al., 2008; Ross et al., 2007). Nevertheless, our findings further support the potential effectiveness of sports-based HIV prevention and demonstrate that a sports-based intervention found successful in improving knowledge and attitudes in sub-Saharan Africa can retain its effect on knowledge, attitudes and communication when adapted to a Caribbean context. Ideally, such interventions should be tested for their effectiveness in reducing HIV and other sexually transmitted infections, pregnancies, and reported sexual risk behaviors.

\section{Acknowledgements}

This research was funded by the Kaminsky Family Fund through Dartmouth College's Dean of Faculty as well as the John Sloan Dickey Center for International Understanding. It was also supported by the Fundación de Libertad, the Lintilhac Foundation, and the William Jewett Tucker Foundation.

\section{Note}

1. The barrios had similar living conditions to bateyes, with extreme poverty, informal housing, and lack of social services.

\section{References}

CESDEM (2007a). Prevalencia de VIH en la República Dominicana, ENDESA 2007.Santo Domingo, Dominican Republic: CESDEM. Retrieved from http:// www.cesdem.com $/ \mathrm{html} /$ prevalencia_de_vih_en_la_rep ublica_dominicana_endesa_2007.pdf

CESDEM (2007b). Encuesta sociodemográfica y sobre VIH/ SIDA en los bateyes estatales de la República Dominicana. Santo Domingo, Dominican Republic: Author.

Clark, T.S., Friedrich, G.K., Ndlovu, M., Neilands, T.B., \& McFarland, W. (2006). An adolescent-targeted HIV prevention project using African professional soccer players as role models and educators in Bulawayo, Zimbabwe. AIDS and Behavior, 10(4 Suppl), S77-S83.

Cowan, F.M., Pascoe, S.J., Langhaug, L.F., Mavhu, W., Chidiya, S., Jaffar, S., . . Regai Dzive Shiri trial team (2010). The Regai Dzive Shiri project: Results of a randomized trial of an HIV prevention intervention for youth. AIDS, 24(16), 2541-2552.

Delva, W., Michielsen, K., et al. (2010). HIV prevention through sport: The case of the Mathare Youth Sport Association in Kenya. AIDS Care, 22(8), 1012-1020.
Ferguson, J. (2003). Migration in the Caribbean: Haiti, the Dominican Republic and beyond. UK: Minority Rights Group International.

Gaillard, E.M., Boulos, L.M., André Cayemittes, M.P., Eustache, L., Van Onacker, J.D., Duval, N., ..., Thimoté (2006). Understanding the reasons for decline of HIV prevalence in Haiti. Sexually Transmitted Infections, 82(Suppl 1), i14-i20.

Halperin, D.T. (1999). Dry sex practices and HIV infection in the Dominican Republic and Haiti. Sexually Transmitted Infections, 75(6), 445-446.

Halperin, D.T., De Moya, A., Pérez-Then, E., Pappas, G., \& Garcia Calleja, J.M. (2009). Understanding the HIV epidemic in the Dominican Republic: A prevention success story in the Caribbean? JAIDS, 51, S52-S59.

Jewkes, R., Nduna, M., Levin, J., Jama, N., Dunkle, K., Puren, A., \& Duvvury, N. (2008). Impact of stepping stones on incidence of HIV and HSV-2 and sexual behaviour in rural South Africa: Cluster randomised controlled trial. BMJ, 337, a506.

Kreniske, J. (1997). AIDS in the Dominican Republic: Anthropological Reflections on the Social Nature of Disease. In Bond, Kreniske, Susser, and Vincent, (Eds.), AIDS in Africa and the Caribbean (pp. 33-50), Westview Press.

Lopéz Severino, I., \& De Moya, A. (2007). Migratory routes from Haiti to the Dominican Republic: Implications for the epidemic and the human rights of people living with HIV/AIDS. Interamerican Journal of Psychology, 41(1), 7-16.

Maro, C.N., Roberts, G.C., et al. (2009). Using sport to promote HIV/AIDS education for at-risk youths: An intervention using peer coaches in football. Scandinavian Journal of Medicine \& Science in Sports, 19(1), 129-141.

Martínez, L. (2005). Entrevista a inmigrantes Haitianos: Comportamiento, percepciones, y prácticas de migrantes haitianos relativos a VIH en zonas altamente pobladas por migrantes haitianos. República Dominicana: MOSCTHA.

PAHO, (2007). Health in the Americas 2007, Volume 1. Washington, D.C.: PAHO.

Plummer, M.L., Ross, D.A., Wight, D., Changalucha, J., Mshana, G., Wamoyi, J., ... Hayes, R.J. (2004). "A bit more truthful": The validity of adolescent sexual behaviour data collected in rural northern Tanzania using five methods. Sexually Transmitted Infections, 80 (Suppl II), ii49-ii56.

Population Services International. (2006, May). Encuesta TRAC: Linea Basal, Proyecto Bateyes. Population Services International, Dominican Republic.

Roman-Poueriet, J., Fernandez, A.D., Beck-Sague, C.M., Garcia Szabo, R., Mercedes, F., Duke, W., et al. (2009). HIV infection and prevention of mother-tochild transmission in childbearing women: La Romana, Dominican Republic, 2002-2006. Rev Panam Salud Publica, 26(4), 315-323.

Ross, D.A., Changalucha, J., et al. (2007). Biological and behavioural impact of an adolescent sexual health 
intervention in Tanzania: A community-randomized trial. AIDS, 21(14), 1943-1955.

SDP IWG. (2008). Hamessing the power of Sport for Development and Peace: Recommendations to Goverments. Right to play. Toronto.

Shelton, J.D., Halperin, D.T., Nantulya, V., Potts, M., Gayle, H.D., \& Holmes, K.K. (2004). Partner reduction is crucial for balanced "ABC" approach to HIV prevention. BMJ, 328, 891-893.
Simmons, D. (2010). Structural violence as social practice: Haitian agricultural workers, anti-haitianism, and health in the Dominican Republic. Human Organization, 69(1), 10-18.

UNAIDS (2008). Report on the global AIDS epidemic. Geneva: UNAIDS. 